https://doi.org/10.15407/scine16.05.079

DUNAYEVSKA, N.I., BONDZYK, D.L., NEHAMIN, M.M., MIROSHNICHENKO, Ye.S., BEZTSENNYI, I.V., EVTUKHOV, V.Ya., and SHUDLO, T.S.

Coal Energy Technology Institute, the NAS of Ukraine,

19 , Andriyivska St., Kyiv, 04070, Ukraine,

+380 44425 5068, ceti@i.kiev.ua

\title{
TECHNOLOGY OF ANTHRACITE AND SOLID BIOFUELS CO-FIRING IN PULVERIZED COAL BOILERS OF TPP AND CHP
}

Introduction. International experience provides many examples of highly efficient use of biomass for heat and electricity production in coal-fired boilers. For Ukraine that has large coal deposits and a potential of solid plant biomass, such technology has not been implemented yet.

Problem Statement. Given the scarcity of anthracite group coal, searching for new non-project fuels for thermal energy is an urgent task in the view of Ukraine's commitment to increase renewable energy production and the need to comply with strict European emission standards.

Purpose. Development of optimal technological and operational conditions for co-firing of anthracite group coal and solid biomass.

Materials and Methods. The objects of research are pulverized Ukrainian coal and solid biomass of plant origin. Experimental research methods with laboratory and pilot plants, as well as CFD modeling have been used.

Results. Blends of coal and biomass burning conditions have been studied; optimal scheme for TPP-210A coal-fired boiler has been recommended; balance calculations in the joint torch that burns anthracite and solid biofuels have been made; according to the chosen design scheme a burner for biomass and coal co-firing for coalfired boilers TPP-210A have been implemented and preliminary design of the burner has been prepared. The project can be used at any TPP-210A power boiler units, and with minor changes at most boilers that burn anthracite and lean coal.

Conclusions. The use of 8-12\% of biomass by heat can essentially intensify the processes of anthracite coal. It is recommended to supply biomass pellets from a separate tank via a special mill to the burner where fuel is injected into the pipeline with a conical divider at output. $3 D$ modeling of co-firing has shown a temperature flow and a fuel burn-out growth. A preliminary design of the boiler burner TPP-210A for co-combustion of anthracite and $10 \%$ biomass has been made.

Keywords: thermal power plants, biofuels, coal, and co-firing.

Citation: Dunayevska, N.I., Bondzyk, D.L., Nehamin, M.M., Miroshnichenko, Ye.S., Beztsennyi, I.V., Evtukhov, V.Ya., and Shudlo, T.S. Technology of Anthracite and Solid Biofuels Co-Firing in Pulverized Coal Boilers of TPP and CHP. Sci. innov. 2020. V. 16, no. 5. P. 79-89. https://doi.org/10.15407/scine16.05.079 
Fuel and environment safety is among the priorities for the successful development of the country. Coal-fired power plants produce up to $37 \%$ of electricity in Ukraine. In recent years, for many reasons, the reserves of fossil fuels have been declining (gas is purchased in limited quantities, anthracite and lean coal have become scarce because of the anti-terrorist operation in eastern Ukraine).

In Western Europe, North America, and Asia, in the last two decades, alternative solid fuels (plant biomass) for co-firing with coal in flare boilers and fluidized bed boilers have been increasingly used in power engineering system [1, 2]. However, the properties of these solid fuels depend significantly on local conditions. Therefore, the experience of Western countries cannot be used in the domestic power engineering and needs to be adapted.

In Ukraine, biomass is used only in small-scale power generation for heating and hot water supply systems. There is no experience in using biomass for power-generating units with a capacity of 200-300 MW. Therefore, to introduce technologies for co-firing of different types of solid fuels, it is necessary to study the peculiarities of mutual influence during their joint combustion.

On its way towards membership in the European Community, Ukraine has committed itself to implementing the environmental conventions, which significantly limits the use of fossils and stimulates demand for alternative renewable fuels.

Biomass is one of the most promising sources, which provides $4 \%$ of humanity's need for primary energy. $72 \%$ of the biomass used for energy purposes is solid biomass. Today, the share of renewable fuels in Ukraine's energy balance is very small. In many Western European countries, especially in the Scandinavian countries, it has exceeded $20 \%$.

Among the ways of solid biomass use, the technology for co-firing of biomass with coal in a flare has become widespread, due to a high efficiency of combustion because of the maximum thermal stress of the furnace volume of pulverized coal boilers and their prevalence in the world. Today, in the world, 243 boilers burn biomass with coal, 93 of which operate on pulverized coal. Developments in the field of improving combustion technologies with the use of renewable fuels are actively carried out [3,4]. Considerable attention is paid to the problems of increasing the reliability of units for combustion of various types of biomass and waste. The most common schemes for co-firing in pulverized coal boilers are joint grinding and combustion of biomass with coal, separate preparation of biomass, its combustion in a combined or separate burner and pre-gasification of biomass followed by its combustion in the boiler $[5,6]$.

Table 1. Technical Analysis of the Studied Fuels

\begin{tabular}{|c|c|c|c|c|c|c|c|c|c|}
\hline \multirow{3}{*}{ Fuel } & \multirow{3}{*}{$\begin{array}{c}\text { Total moisture } \\
\text { content as } \\
\text { received, } \\
W_{t}^{r}, \%\end{array}$} & \multirow{3}{*}{$\begin{array}{c}\text { Ash content } \\
\text { in dry fuel, } \\
A^{d}, \%\end{array}$} & \multirow{3}{*}{$\begin{array}{c}\text { Total sulfur } \\
\text { content } \\
\text { in dry fuel, } \\
S_{t}^{d}, \%\end{array}$} & \multirow{3}{*}{$\begin{array}{l}\text { Volatile } \\
\text { matter, } \\
V^{\text {Ilaf }} \%\end{array}$} & \multicolumn{3}{|c|}{ Ash fusibility, ${ }^{\circ} \mathrm{C}$} & \multirow{2}{*}{\multicolumn{2}{|c|}{$\begin{array}{c}\text { Calorific value } \\
\text { Lower, } Q_{i}^{r}\end{array}$}} \\
\hline & & & & & \multirow{2}{*}{$t_{A}$} & \multirow{2}{*}{$t_{B}$} & \multirow{2}{*}{$t_{C}$} & & \\
\hline & & & & & & & & $\mathrm{MJ} / \mathrm{kg}$ & $\mathrm{kcal} / \mathrm{kg}$ \\
\hline Pine pellets & 8.7 & 0.4 & 0.03 & 85.9 & 1300 & 1310 & 1325 & 17.63 & 4211 \\
\hline $\begin{array}{l}\text { Agropellets (straw of } \\
\text { agricultural crops) }\end{array}$ & 8.4 & 6.1 & 0.14 & 82.0 & 1180 & 1200 & 1225 & 15.57 & 3720 \\
\hline Sunflower husk pellets & 9.3 & 9.7 & 0.18 & 80.3 & 1100 & 1110 & 1200 & 14.81 & 3538 \\
\hline Milled coal (sample 1) & 1.6 & 36.6 & 1.19 & 13.6 & 1390 & $>1400$ & $\mathrm{n} / \mathrm{d}$ & 19.04 & 4547 \\
\hline Milled coal (sample 2) & 6.0 & 19.0 & $\mathrm{n} / \mathrm{d}$ & 14.7 & $\mathrm{n} / \mathrm{d}$ & $\mathrm{n} / \mathrm{d}$ & $\mathrm{n} / \mathrm{d}$ & 25.5 & 6081 \\
\hline
\end{tabular}

Note. $t_{A}$ is temperature of initial deformation; $t_{B}$ is hemisphere melting point; $t_{C}$-is temperature of the liquid-melting state; $\mathrm{n} / \mathrm{d}$ could not be determined. 
This type of fuel is not foreseen for most boilers of Ukrainian TPPs, so it requires a significant amount of research on combustion properties and assessment of the impact of biomass on coal in the processes of their co-firing. This will determine the optimal ratios of fuels and combustion conditions, which make it possible to reduce the total cost of fuel and harmful emissions and to promote the country's energy independence.

The analysis of world experience in commercial use of co-firing technology at thermal power plants allows us to make the following conclusions:

- Co-firing of biomass with coal, lignite and peat in conventional steam boilers provides a unique opportunity, combining the utilization of renewable energy sources and fossil fuels, to derive the most advantage from both fuels;

- adding biomass to fuel may significantly reduce emissions of carbon dioxide and other pollutants into soil and air;

- up to $10 \%$ of coal burned in a boiler with minor equipment changes may be easily replaced by co-firing of biomass in pulverized coal boilers, which is extremely important, given Ukraine's limited opportunities to invest in equipment modernization. This is also a promising option for the joint combustion of Ukrainian anthracite, since the excessive content of volatile substances in biomass can compensate for the lack of volatile substances in coal;

- the use of biomass in the power engineering sector of Ukraine has not been studied in detail. There is no database on plant biomass properties in Ukraine.

To conduct research for determining the optimal biomass/coal ratio, a pilot plant that simulates the processes occurring in the combustion chamber and the lower reaction part (LRP) of the combustion installation. The Institute of Coal Energy Technologies of the National Academy of Sciences of Ukraine has the unique pilot plant that allows the combustion of pulverized solid fuel in stream, at a temperature up to $1700^{\circ} \mathrm{C}$. It is equipped with supply systems for different types of fuels: auger-type biomass feeder, drum fee- der of coal dust, and natural gas supply system. In [7], the plant and methods with working out the co-combustion of different fuels have been described in detail.

The analysis of the technical characteristics of the studied fuels and their elemental composition is given in Table 1 and Table. 2, respectively. For the second sample of coal dust it has not been possible to obtain a complete elemental analysis and ash melting point. Although originally it was planned to study co-firing of biomass and anthracite (as a typical design fuel for Trypillya TPP and many others), in the short term, the situation in the coal market changed dramatically (blockade of uncontrolled portions of the Donetsk and the Luhansk Oblasts, sanctions). In the second half of 2017, the anthracite reserves of Ukrainian TPPs (that according to the design, operate on anthracite coal) were practically exhausted. According to data of the thermal power plant and analysis of two samples of coal dust taken there, at that time the main fuel for anthracite TPP was lean coal with different ash content (volatile matter per combustible mass ( $V^{\text {Iaf }}$ ) is up to $18 \%$ ) (Table 1). The first sample of coal had a very high ash content ( $A^{d}$ over $36 \%$ ) and a high ash melting point (the temperature of the normal liquid-melting state for it is more than $1550^{\circ} \mathrm{C}$, which makes it impossible to stably and reliably burn it on the pilot plant). Therefore, the second sample (lean coal) with an ash content of $19.0 \%$ (dry basis) was chosen as main fuel.

Table 2. Element Composition of the Studied Fuels

\begin{tabular}{|c|c|c|c|c|c|c|}
\hline \multirow[b]{2}{*}{ Fuel } & \multirow{2}{*}{$\begin{array}{c}\text { Chlorine } \\
\text { content } \\
\text { in dry } \\
\text { fuel, } \\
\mathrm{Cl}^{d}, \%\end{array}$} & \multicolumn{5}{|c|}{ Element composition, \% } \\
\hline & & $C^{\text {daf }}$ & $H^{\text {daf }}$ & $O^{d a f}$ & $N^{\text {daf }}$ & $S^{\text {daf }}$ \\
\hline Pine pellets & 0.04 & 51.87 & 6.33 & 41.63 & 0.14 & 0.03 \\
\hline $\begin{array}{l}\text { Agropellets (straw of } \\
\text { agricultural crops) }\end{array}$ & 0.27 & 50.30 & 6.21 & 42.81 & 0.53 & 0.15 \\
\hline $\begin{array}{l}\text { Sunflower husk pel- } \\
\text { lets }\end{array}$ & 0.42 & 49.35 & 6.20 & 43.35 & 0.89 & 0.21 \\
\hline Milled coal (sample 1) & 0.62 & 88.97 & 3.24 & 5.63 & 1.30 & 0.86 \\
\hline Milled coal (sample 2) & $\mathrm{n} / \mathrm{d}$ & $\mathrm{n} / \mathrm{d}$ & $\mathrm{n} / \mathrm{d}$ & $\mathrm{n} / \mathrm{d}$ & $\mathrm{n} / \mathrm{d}$ & 0.84 \\
\hline
\end{tabular}

Note. N/d could not be determined . 
The comparison of fuel properties has allowed a priori anticipation of the following benefits of the co-firing technique:

1) significantly lower ash content enables the use of lean coal with a high ash content (similar to the sample 1) as main fuel; while burning coal with a conventional ash content (20-24\%), the use of biomass reduces volatile ash emissions;

2 ) the sulfur content in biomass is 5-50 times lower than in coal, which significantly reduces the formation and emissions of harmful $\mathrm{SO}_{2}$ gas and, consequently, environmental pollution and emissions charges for thermal power plants;

3 ) high content of combustible volatile matter ( $V^{\text {laf }}>80 \%$ ) helps ignite the coal and can formally upgrade the coal mix from the anthracite coal to the lean coal;

4) lower ash melting point can improve the yield of liquid slag;

5) lower nitrogen content in the combustible mass (up to 10 times) reduces emissions of "fuel" nitrogen oxides.

However, when planning the experiments, the following factors should take into account:

1) high content of volatile substances can cause ignition of biomass, which requires safety measures in the system of storage and transportation of biomass;

2) low ash softening temperature of sunflower husk pellets $\left(t_{A}=1100^{\circ} \mathrm{C}\right)$ may lead to slagging of heating surfaces of a boiler unit. A trial in a real boiler is required;

3) low heat of biomass combustion may reduce the adiabatic combustion temperature of the fuel mix, but the actual temperature will depend on many factors (rapid release and combustion of volatile substances helps ignite coal dust).

The experiments were made with each type of biomass (pine, agropellet and sunflower husk pellets, and different share of biomass in the mix, from 3.5 to $20 \%$ ). Their results have shown that:

- it is possible to burn together in flare boilers lean coal and milled pellets of biomass of Ukrainian origin;
- the addition of biomass in the process of burning coal intensifies its ignition and raises the temperature in the combustion installation in the immediate vicinity of the burner;

- the share of biomass over $15-20 \%$ may lead to overheating of the heating surfaces of the lower reaction part and will require the reconfiguration of the combustion installation;

- the optimal share of biomass, which intensifies coal combustion, but does not require significant modifications of the burner and boiler ranges within $8-12 \%$, so we can recommend $10 \%$ share of biomass as a technologically acceptable and efficient share in terms of heat in the total amount of fuel.

\section{CO-FIRING BURNER CONFIGURATION}

Given the above, the choice of the optimal biomass/coal ratio is based on technologically, environmentally, and economically sound indicators in order to maintain reliable and safe operation of all systems of existing boilers.

The vortex burner of the TPP-210A boiler with a thermal capacity of $70 \mathrm{MW}$ Trypillya TPP, in Kyiv Oblast, in the area of which, at an economically reasonable distance, there are many woodworks waste (biomass) is to be minimally upgraded.

This typical burner has the following specifications.

Total length, $\mathrm{m} \quad \ldots \ldots \ldots \ldots \ldots \ldots \ldots \ldots$

Diameter of the central air channel, $\mathrm{m} . . . \quad 0.67$

Diameter of the air mix channel with the

primary air, $m \ldots \ldots \ldots \ldots \ldots \ldots \ldots$

Diameter of the first channel of secondary

air, $m \ldots \ldots \ldots \ldots \ldots \ldots \ldots \ldots$

Diameter of the second channel of secon-

dary air, $m \ldots \ldots \ldots \ldots \ldots \ldots \ldots \ldots \ldots \ldots$

Design air consumption, $\mathrm{nm}^{3} / \mathrm{h}$ :

Central ..................

Primary.....................

Secondary $\ldots \ldots \ldots \ldots \ldots \ldots \ldots \ldots$

Total

0.96

Rest of

(3)

1.3

1.5

Temperature before the burner input, ${ }^{\circ} \mathrm{C}$ :

Air ...........................

Primary air mix

$340-360$

220 
Design coal consumption at the nominal

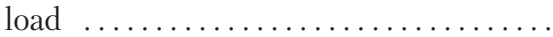

Coal properties:

Anthracite $A^{d}=19.0 \%, W_{t}^{r}=7.5 \%, Q_{i}^{r}=24.26 \mathrm{MJ} / \mathrm{kg}$;

Coal dust $Q_{i}^{r}$ at $W_{t}^{r}=1 \%$ is $25.9 \mathrm{MJ} / \mathrm{kg}$.

In order to ensure the passage of biomass through the central air channel, the flow rate shall be, at least, $20 \mathrm{~m} / \mathrm{s}$. To do this, while ensuring the supply of biomass in the amount of $10 \%$ of high- concentration coal in terms of heat, the consumption of biomass with a calorific value of $4211 \mathrm{kcal} / \mathrm{kg}$ per burner shall be $1.5 \mathrm{t} / \mathrm{h}$.

To ensure the heating of coal by the volatile biomass combustion products, the biomass flow shall be twisted with the torsion parameter of $\mathrm{n}=2$ or a divider shall be installed at the channel outlet.

The coaxial channel that will be formed during the upgrade of the burner for biomass-coal cofiring, shall be supplied with air at a flow rate of, at least, $3000 \mathrm{~m}^{3} / \mathrm{h}$ (Fig. 1).

The regulation of the total air flow to the burner remains unchanged and is carried out by varying the secondary air flow.

\section{SCHEME OF BIOMASS SUPPLY TO TPP-210A BOILER}

Given a high capacity of the pulverized coal unit of Trypillya TPP and a significant difference in the properties of coal and biomass, it has been proposed to provide the ability to replace anthracite by pellets, up to $10 \%$ in terms of heat. It is planned to place a system of storage, transportation, dosage, and supply of solid biomass pellets in all 12 burners of the TPP-210A boiler. It is necessary to test technical solutions and to demonstrate how the technology works, with the possibility of its further improvement in Ukraine.

The general scheme of the system for pelleted fuel supply to the boiler is illustrated in Fig. 2.

The pulverized coal boiler TPP-210A at Trypillya TPP consists of two drums, with 6 burners installed in one tier, in the combustion installation of each drum. Biomass is supplied to the central channel of the boiler burners. The option of pneumatic transport of high-concentration pellets from the feed hopper to a burner under rarefaction with use of a steam ejector is preliminary

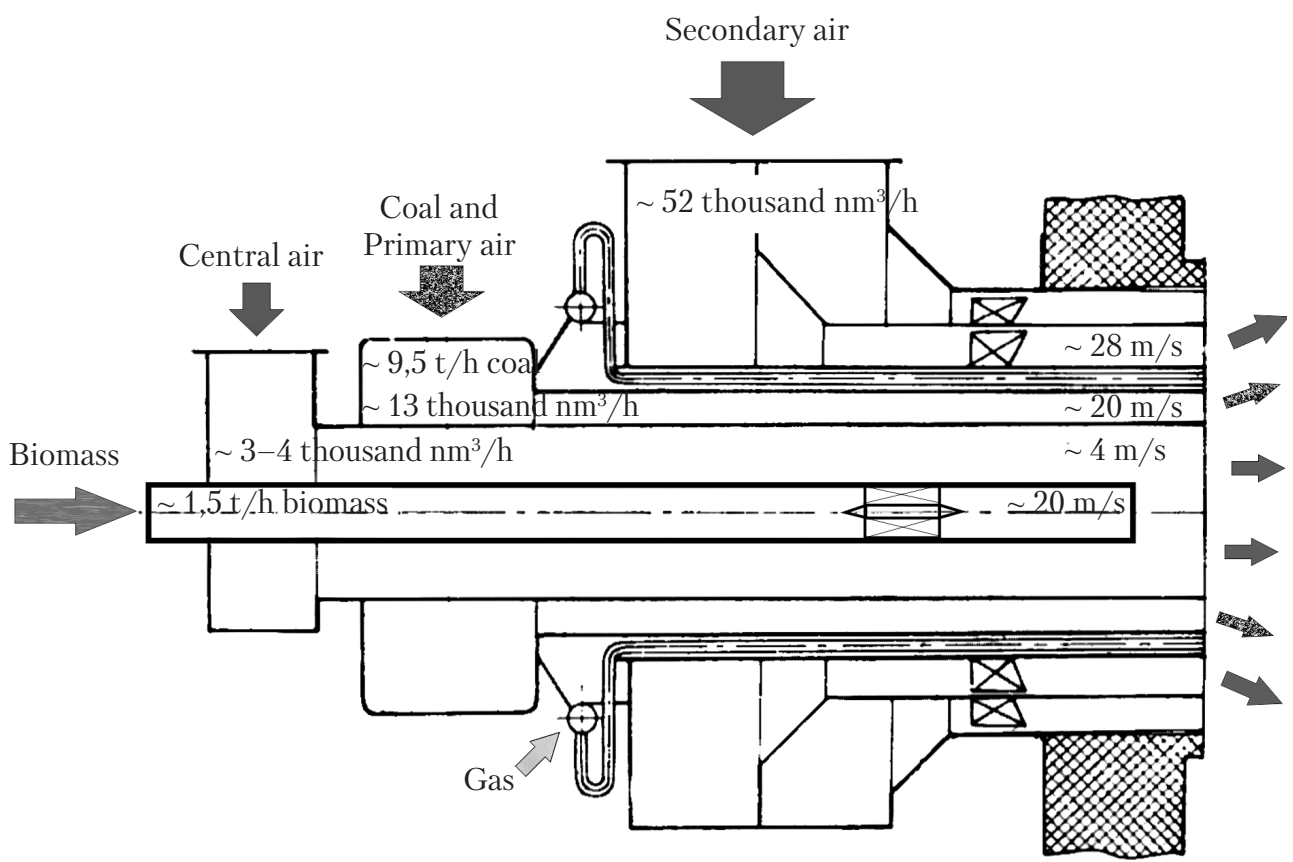

Fig. 1. TPP-210A boiler burner for co-firing of coal and biomass, capacity $70 \mathrm{MW}$ 


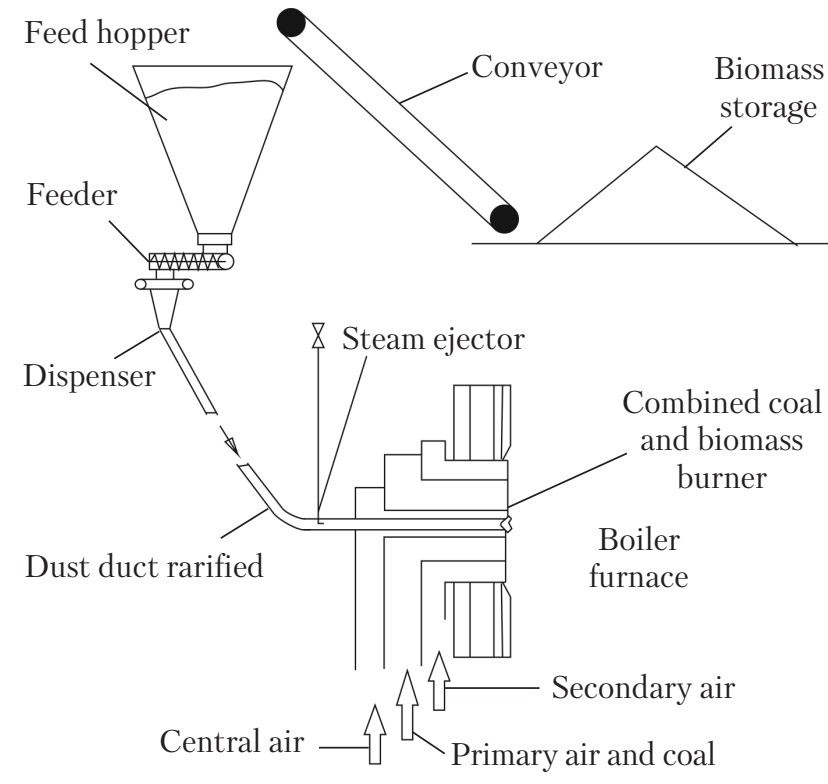

Fig. 2. Scheme of biomass supply to upgraded burner

considered. Having passed the feeder, pellets can be crushed, for example, with the use of a fan mill. In the biomass input channel a constant air flow rate is maintained, with the air speed ensuring a stable fuel supply and with the flow of pellets regulated by the feeder. As shown above, the replacement of $10 \%$ of coal with biomass requires the consumption of $1.5 \mathrm{t} / \mathrm{h}$ milled pellets per burner. To ensure a continuous supply of biomass for 8 hours in one burner and a bulk density of biomass of $0.7 \mathrm{~kg} / \mathrm{m}^{3}$, the volume of the feed hopper should be $17 \mathrm{~m}^{3}$.

\section{D-SIMULATION OF ANTHRACITE AND BIOMASS CO-FIRING IN THE COMBUSTION INSTALLATION OF TPP210A BOILER}

One of the methods for studying the influence of adding biomass to anthracite fuel on the parameters of the process of their co-firing is numerical simulation. The research uses the well-known program ANSYS FLUENT, but it is necessary to briefly explain certain features of such a task in this program.

The ANSYS FLUENT program, according to its documentation, allows modeling of co-firing of solid fuel dust and gaseous or liquid fuel. The possibility of using other solid fuels in the model instead of it (which is technically possible) is our assumption that is necessary to be analyzed and confirmed.

The test calculations with the simultaneous introduction of anthracite and pine pellets into the computation domain have given results close to those expected, which can be interpreted as confirmation of the possibility of the approach used.

Regarding industrial conditions, the results of coal and biomass co-firing have been considered by the example of processes in TPP-210A fuel boilers [8]. The particle size of the coal is taken according to the Rosin-Rammler distribution in the range from 5 to $200 \mu \mathrm{m}$ with an average particle size of $40 \mu \mathrm{m}$. The particle size of the pellets is $200 \mu \mathrm{m}$, since increasing this size dramatically worsens the pellet burnup. In the calculations, such a small size can be justified by the assumption that because of a high percentage of volatile compounds (and moisture content), while heated in the flow, large particles of pellets may break into smaller ones. The consumption of coal dust is set for the nominal load, the oxidant oversupply coefficient $\alpha_{\mathrm{T}}=1.25$, including the suction coefficient $\alpha_{\text {прис }}=0.05$. The technical and elemental analysis and lower calorific value used in the calculations of anthracite and pine pellets are given in Table 3 .

In the pellet mode, the pellet consumption rate is chosen based on considerations of the conservation of fuel thermal energy with regard to the "no pellet" mode, with the ratio of heat produced by coal and pellets 9:1. The oxidant consumption is determined by the above values of the oxidant oversupply coefficient, given the difference in its amount for the combustion of coal and pellets. The twist angle is 20 degrees for the central air, and 25 and 50 degrees for the air mix and secondary air, respectively.

In the calculations, several options for the place of pellet feed have been tested: along the axis of the central air of the burners on the divider, together with the air mix; in the discharge nozzles; 

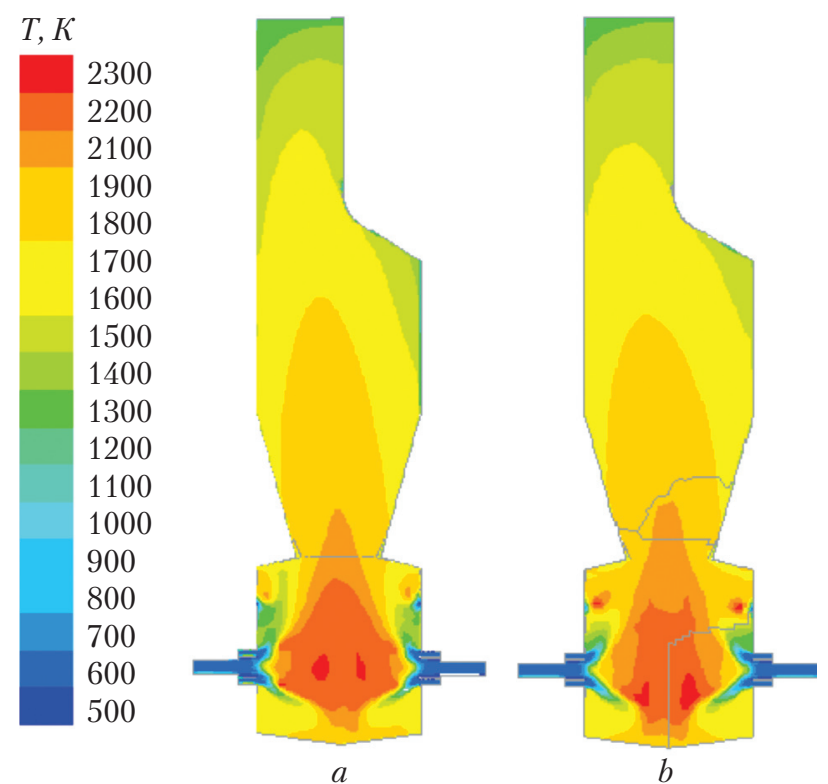

Fig. 3. Temperature fields in the plane $z=0$ for the options of combustion installation design without biomass $(a)$ and with biomass fed to air mix $(b)$

and below the burners. The influence of the place of biomass feed on the pre-combustor temperature fields, burnout intensity, oxygen concentration, and flow rate fields has been considered in detail. It follows from the results that an increase in the average flow temperature at the exit from the computation domain by $35-40^{\circ} \mathrm{C}$ when feeding pellets almost does not depend on the place of their feed to the pre-combustor. The oxygen concentration at the outlet varies slightly. The place of pellet feed most significantly affects the completeness of anthracite burnout in the pre-combustor. In all cases, it increases, as compared with the "no pellet" mode, and shows the most significant growth (by 2.8\%) if pellets are fed into the discharge nozzles. However, for this option, the lowest burnout of pellet coke is reported. Al-

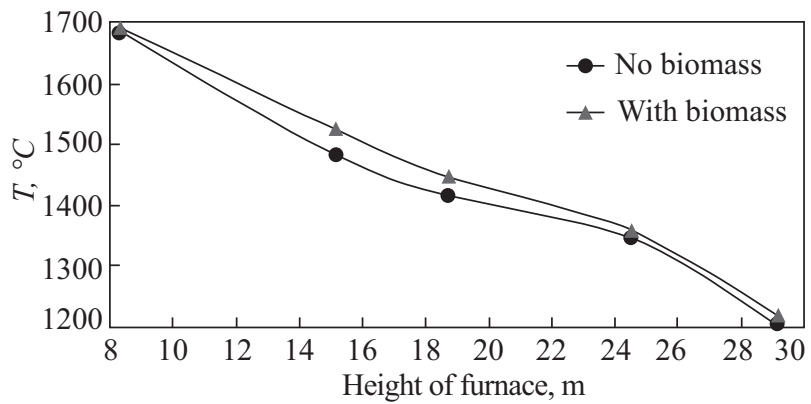

Fig. 4. Change in average temperature of gaseous phase along the height of combustion installation

though this fact shall not be decisive in choosing the place of pellet feed because, firstly, as one can see from Table 2, there is a small coke residue in the pellets (and their volatile substances in all options burn completely), and, secondly, in this case, we deal with burnout in the lower reaction part, while in the combustion installation, the fuel pellets burn down completely, as shown by the calculations. In general, in our opinion, the calculations have not shown a clear advantage of any particular place of pellet feed.

For calculations of combustion in the combustion installation, it is divided into 5 zones, and the boundary conditions, the average wall temperature and radiation coefficients, are used according to the results of zonal calculations by the normative method. For zones $1-5$, they amount to $849-1372{ }^{\circ} \mathrm{C}$ and $0.68-0.75$, respectively. The parameters in the combustion installation have been calculated for the options without feed of biomass into stream and with its feed into air mix. The corresponding temperature fields, as shown in Fig. 3, do not differ significantly. The flow temperature distributions along the combustion installation height (Fig. 4) are also quite close,

Table 3. Anthracite and Pellets Properties

\begin{tabular}{|l|c|c|c|c|c|c|c|c|c|c|}
\hline \multirow{2}{*}{ Fue } & \multicolumn{4}{|c|}{ Technical analysis, \% } & \multicolumn{5}{c|}{ Element composition, \% } & Calorific value \\
\cline { 2 - 11 } & $A^{r}$ & $W^{r}$ & $V^{r}$ & $C^{s}$ & $C^{r}$ & $H^{r}$ & $O^{r}$ & $N^{r}$ & $S^{r}$ & $Q_{i}^{r}, \mathrm{MJ} / \mathrm{kg}$ \\
\hline Anthracite & 19 & 7.5 & 4 & 69.5 & 68.00 & 1.45 & 1.90 & 0.58 & 1.57 & 24.23 \\
Pellets & 0.365 & 8.7 & 78.43 & 12.51 & 47.17 & 5.756 & 37.86 & 0.127 & 0.027 & 17.63 \\
\hline
\end{tabular}


although they increase slightly in the case of biomass supply. The burnout of the coke residue during the supply of biomass remains almost unchanged.

In our opinion, the numerical simulation of processes in TPP-210A fuel boilers for the cases of burning anthracite and anthracite blended with pellets has confirmed certain advantages of the mix.

\section{CONCEPT DESIGN OF THE BURNER}

The main condition for the design works is keeping the existing infrastructure and configuration of the main elements of the burner. According to previous studies, the condition for ignition and co-firing of milled solid biomass and anthracite is to arrange a separate biomass supply channel within the existing burners.

From the biofuel storage, the milled pellets are fed to production in the amount as determined by the relevant calculations.
From the input collectors of steam superheater

$$
P_{\text {max }}=37 \mathrm{kgs} / \mathrm{cm}^{2}, t_{\text {max }}=450{ }^{\circ} \mathrm{C}
$$

Pressure

controller,

controlled from

the main contro
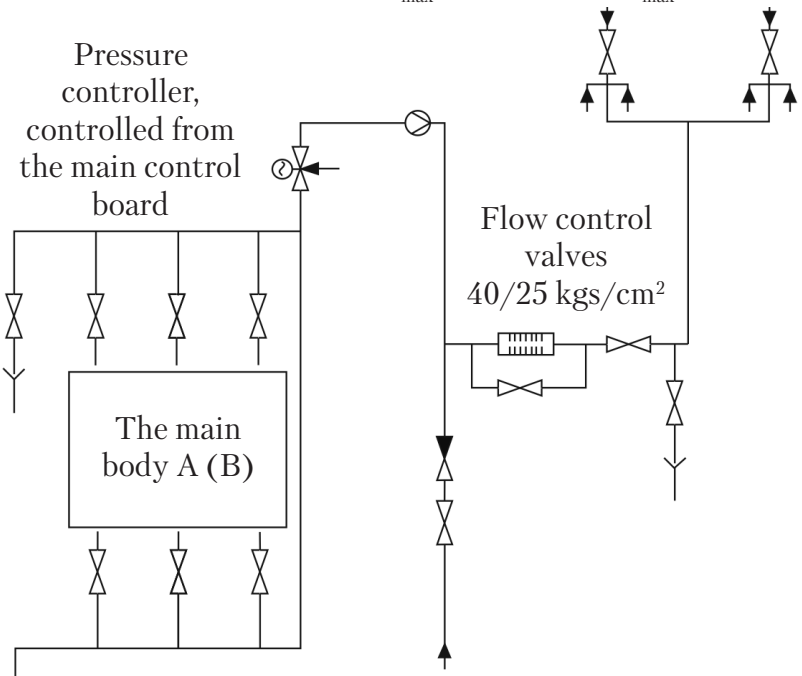

Flow control

valves $40 / 25 \mathrm{kgs} / \mathrm{cm}^{2}$

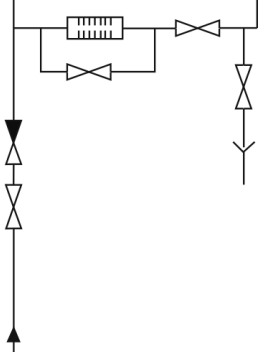

From the collector

$13 \mathrm{~atm}$

Fig. 5. Steam supply system to solid biofuel transport

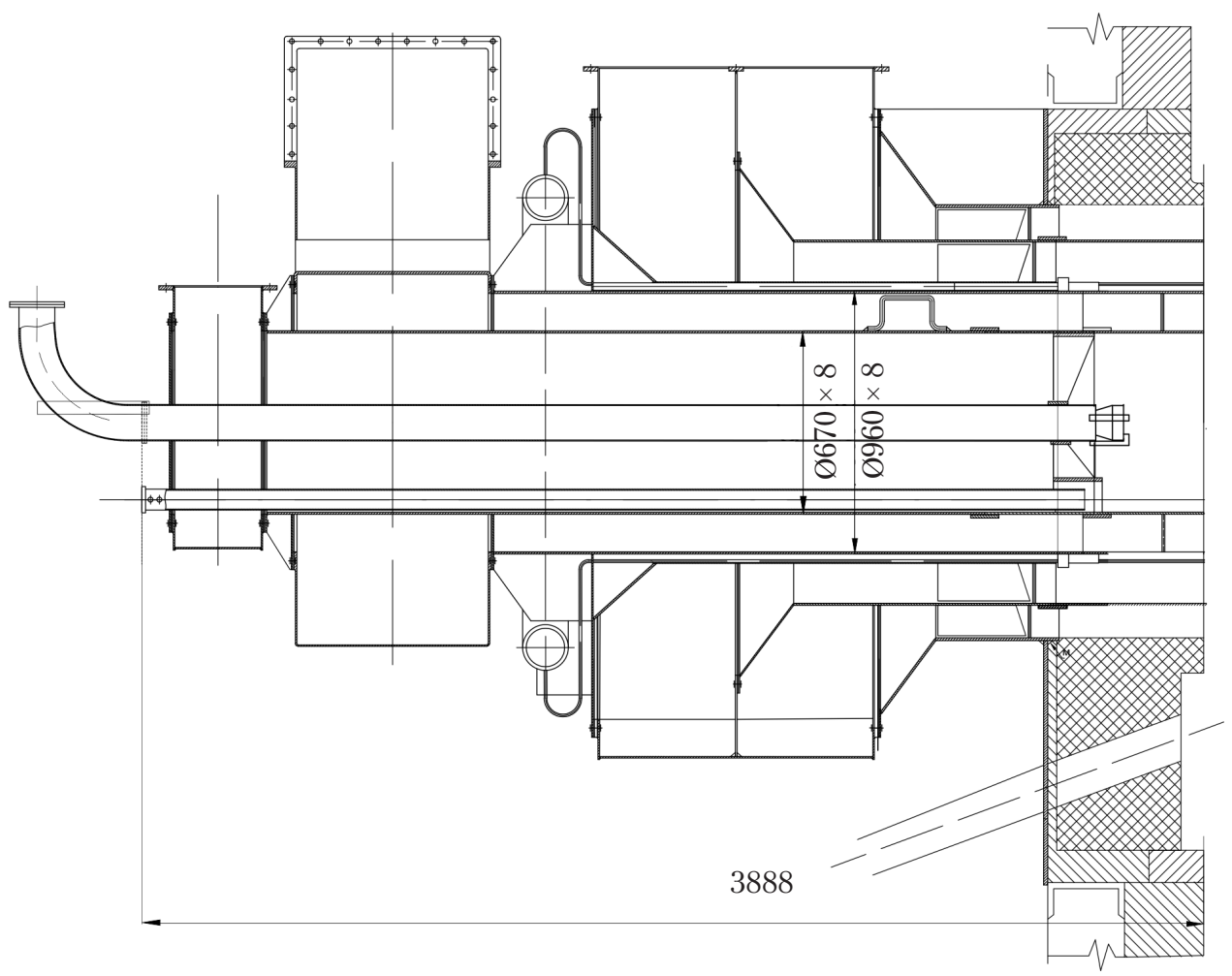

Fig. 6. Concept design of TPP-210A boiler burner upgraded for co-firing of anthracite and $10 \%$ of biomass 
For transporting, a closed spiral conveyor with a flexible screw, or belt conveyor, or high-concentration pneumatic transport is used.

In the hopper-and-deaerator room, in a free space, the feed hopper is installed, its volume is calculated within the scope of other research on logistics and transport of biomass.

Biofuel is dosed from the feed hopper with the help of screw feeders that are driven by electric motors at a variable rotation number. The rotation number of the feeders is regulated by frequency converters. The feeder control system is integrated with the automatic process control system (APCS) of the power generating unit and comes from the unit's control panel.

The number of feeders can correspond to the number of dust pipes, 6 per one drum. In order to save space in the boiler area and capital costs, a scheme can be adopted with the supply from one feeder to 2 dust pipes.

Based on the technical solution described above, the biomass, is supplied to the burner by means of a steam ejector and transported by highly concentrated air.

An approximate scheme of steam supply to the ejectors of the solid biofuel transport system is shown in Fig. 5. The smaller diameter does not ensure a reliable passage of biofuel particles and creates conditions for clogging of biomass ducts. Steam for the transport of solid biofuels is taken from the intermediate superheating collectors. The reserve source of steam is the general station collector (pressure is $13 \mathrm{~atm}$ ). To obtain the specified steam parameters, a remote electric steam pressure regulator for dust transport shall be installed. The steam consumption per 1 burner may be about $70 \mathrm{~kg} / \mathrm{h}$. A refractory metal divider shall be installed at the end of the outlet pipe.

According to the solution, the biomass supply system is integrated into the central air channel, on the side of the main oil sprayer. The control system of the steam pressure regulator, steam pressure sensors, discharge sensors, and dust pipeline temperature sensors are connected to the APCS.
The concept design of the burner of the TPP210A boiler upgraded for burning anthracite and $10 \%$ of solid biofuel is shown in Fig. 6.

\section{CONCLUSIONS}

1. The world experience of co-firing of biomass and coal has shown the possibility of using pulverized coal boilers for this purpose, while maintaining the possibility of their operation both exclusively on coal and with a rapid switch to cofiring of coal and biomass.

2. In the case of biomass share of, at most, $20 \%$ in terms of heat production, neither material boiler reconfiguration nor large capital expenses are required for conversion to co-firing of coal with biomass.

3. The experiments have shown that the use of $8-12 \%$ of biomass in terms of heat can significantly intensify the combustion of anthracite coal.

4. The recommended scheme of biomass supply to the combustion installation is feeding from a separate pellet hopper through a special mill by high-concentration duct to the burner, where it enters the combustion installation via a duct with a conical divider at the outlet.

5. The 3D modeling of co-firing of coal dust and biomass has shown an increase in the flow temperature and fuel burnout.

6 . The concept design of the TPP-210A boiler burner for co-firing of anthracite and $10 \%$ of the biomass with minimal burner modifications has been developed.

7. The developed project can be implemented at any power plants with TPP-210A boilers and, with minor modifications, at most stations that burn anthracite and lean coal.

The research has been further developed, which is reflected in publications of 2018 [9-11].

The research contains experimental results and technical developments obtained at the Institute of Coal Energy Technologies of the NAS of Ukraine while implementing the R\&D innovation project Development of a Technology and a Burner for Co-Firing of Anthracite and Solid Biofuels in TPP-210A Boilers at Trypillya TPP. 


\section{REFERENCES}

1. Dunaevskaia, N. Y., Zasiadko, Ya. Y., Shupyk, Y. S. (2007). Technology of biomass and pulverized coal co-combustion in furnaces. Energy Technologies and Resource Saving, 3, 3-8 [in Russian].

2. Dunayevska, N. I., Volchyn, I. A., Zasiadko, Ya. I., Potapov, A. A., Shchudlo, T. S. (2011). Experience of biomass with coal co-firing in existing power boilers. Energy Neros, 12, 34-43 [in Ukrainian].

3. Yao, YAO, Sheng-Li, MENG, Xuan, QI., Wei-guo, YAO. (2017). TG-Curve Fitting Study of Biomass-Coal Co-Combustion. International Conference on Electronic, Control, Automation and Mechanical Engineering Nov. 19-20, 2017, Sanya, China. p.743-748. URL: http://dpi-proceedings.com/index.php/dtetr/article/view/18486/17985 (Last accessed: 26.11.2019)

4. Park, H. Y., Park, Y. H., Kim, Y. J., Kim, H. H., Park, S. B. (2017). The Interaction of woody biomass with bituminous coal in their blends. Environmental Engineering Research, 22(3), 320-328. doi: https://doi.org/10.4491/eer.2016.159 URL: http://eeer.org/journal/view.php?number=845. (Last accessed: 26.11.2019).

5. Roni, M. S., Chowdhury, S., Mamun, S., Marufuzzaman, M., Lein, W., Johnson, S. (2017). Biomass co-firing technology with policies, challenges, and opportunities: A global review. Renewable and Sustainable Energy Review⿻s, 78, 1089-1101. https://doi.org/10.1016/j.rser.2017.05.023 (Last accessed: 26.11.2019).

6. Lu, G., Yan, Y., Cornwell, S., Whitehouse, M., Riley, G. (2008). Impact of co-firing coal and biomass on flame characteristics and stability. Fuel, 87, 1133-1140.

7. Dunaievska, N. Chernyavskiy, M., Shchudlo, T. (2016). Co-combustion of solid biomass in pulverized anthracite-coal firing boilers. Ukrainian Food Journal, 5(4), 748-764. doi: https://doi.org/10.24263/2304-974X-2016-5-4-14 (Last accessed: 26.11.2019).

8. Dunayevska, N. I., Zasiadko, Ya. I., Zasiadko, P. Ia., Shchudlo, T. S. (2017). Mathematical model of biomass with coal cofiring in the thermal power plant's boiler. Electronic Modeling, 39(3), 89-104 [in Ukrainian].

9. Dunayevska, N. I., Zeniuk, O. Iu., Kolomiichenko, M. V., Mykhailov, M. P., Miroshnychenko, Ye. S., Kravets, P. P., ... Podolets, R. Z. (2018). Coal and biomass co-firing - the real way to ensure diversification of fuel and reduce the impact of thermal power plants on the environment. Energy and Electrification, 6(416), 17-24 [in Ukrainian].

10. Natalya Dunayevska, Yaroslav Zasiadko, Taras Shchudlo. (2018). Thermal destruction kinetics of coal and solid biomass mixtures. Ukrainian Food Journal, 7(4), 738-752. doi: https://doi.org/10.24263/2304-974X-2018-7-4-17 (Last accessed: 26.11.2019).

11. Dunayevska, N. I., Zasiadko, Ya. I., Shchudlo, T. S. (2018). The study of the kinetics of thermal degradation of coal and solid biomass mixtures. Electronic Modeling, 40(5), 91-110 [in Ukrainian].

Received 27.11.19

Revised 27.01.20

Accepted 17.02.20

Н.І. Дунаєвська, Д.Л. Бондзик,

М.М. Нехамін, С.С. Мирошніченко, І.В. Безценний,

В.Я. Євтухов, Т.С. Щудло

Інститут вугільних енерготехнологій Національної академії наук України

вул. Андріївська, 19, Київ, 04070, Україна,

+38044425 5068, ceti@i.kiev.ua

ТЕХНОЛОГІЯ СПІЛЬНОГО СПАЛЮВАННЯ

АНТРАЦИТУ ТА ТВЕРДОГО БІОПАЛИВА

В ПИЛОВУГІЛЬНИХ КОТЛАХ ТЕС І ТЕЦ

Вступ. Світовий досвід дає багато прикладів високоефективного використання біомаси для вироблення тепла та електроенергії в вугільних котлоагрегатах. Проте для України, яка має значні поклади вугілля та потенціал твердої рослинної біомаси, така технологія досі не реалізована.

Проблематика. Пошук нових непроєктних палив для теплової енергетики у зв'язку з дефіцитом вугілля антрацитової групи є актуальним завданням, зважаючи на зобов'язання України збільшити виробництво енергії із відновлюваних джерел та необхідністю виконувати жорсткі європейські норми за викидами.

Мета. Розроблення оптимальних технологічних та режимних умов зі спільного спалювання вугілля антрацитової групи та твердої біомаси. 
Матеріали і методи. Об’єктами досліджень були пилоподібне вугілля українських покладів та тверда рослинна біомаса. Використано експериментальні методи досліджень на лабораторних та пілотних установках, а також CFDмоделювання.

Результати. Досліджено режими горіння суміші вугілля та біомаси; розроблено оптимальну схему їі використання на пиловугільних котлах ТПП-210А; виконано балансовий розрахунок пальника при спільному спалюванні антрациту та твердого біопалива; виконано проєктування пальникового пристрою для котлів ТПП-210А та підготовлено ескізний проєкт. Розроблений проєкт може бути використано на котлах ТПП-210А, а з невеликими змінами - на більшості котлів, які спалюють антрацит та пісне вугілля.

Висновки. Застосування 8-12 \% біомаси за теплом здатне суттєво інтенсифікувати процеси горіння вугілля антрацитової групи. Рекомендована схема подавання біомаси до паливні - з окремого бункеру пелет через подрібнювач до пальника, де вводиться до паливні трубопроводом з конусним розсікачем на виході. 3D-моделювання спільного горіння показало зростання температури потоку й ступеню вигорання палива. Виконано ескізний проєкт пальника котла ТПП-210А для спільного спалювання антрациту та 10 \% частки біомаси.

Ключові слова: теплові електростанції, біопаливо, вугілля, спільне спалювання. 